\title{
EGR1 Gene
}

National Cancer Institute

\section{Source}

National Cancer Institute. EGR1 Gene. NCI Thesaurus. Code C99599.

This gene is involved in transcriptional regulation. 